\title{
Correction to: Don't be Evil: Should we Use Google in Schools?
}

\author{
Daniel G. Krutka ${ }^{1}$ (D) Ryan M. Smits ${ }^{1} \cdot$ Troy A. Willhelm ${ }^{1}$
}

Published online: 20 April 2021

(C) Association for Educational Communications \& Technology 2021

\section{Correction to: TechTrends https://doi.org/10.1007/s11528-021-00599-4}

The original article unfortunately contained 2 errors.

1. "Authors (2019)" is still showing in the first paragraph of the "Implications". It should be "Krutka et al. (2019).

2. The note reference section "Several Publications by Authors Have Been Removed for the Peer Review Process" should be deleted.

The original article has been corrected.

Publisher's Note Springer Nature remains neutral with regard to jurisdictional claims in published maps and institutional affiliations.

The online version of the original article can be found at https://doi.org/ 10.1007/s11528-021-00599-4

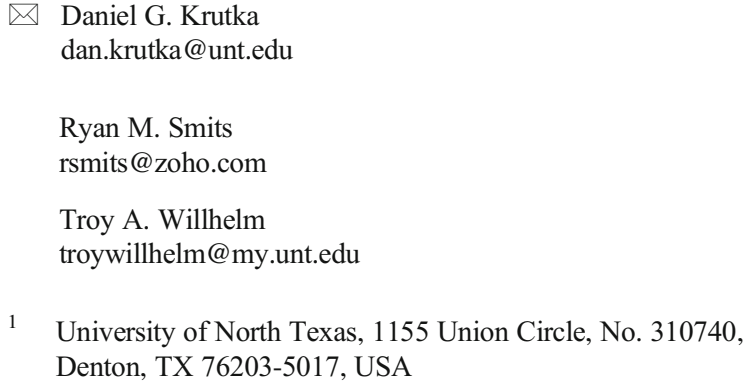

